\title{
Pendidikan Nasionalisme di Era Society 5.0: Revitalisasi Peran Keluarga dan Masyarakat
}

\author{
(Nationalism Education in Era Society 5.0: \\ Revitalizing the Role of the Family and Society)
}

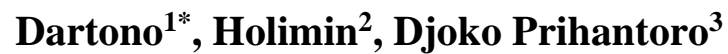 \\ ${ }^{1}$ Teknik Aeronautika Pertahanan Akademi Angkatan Udara, Yogyakarta \\ ${ }^{2}$ Teknik Elektronika Pertahanan, Akademi Angkatan Udara, Yogyakarta \\ ${ }^{3}$ Teknik Manajemen Industri Pertahanan Akademi Angkatan Udara, Yogyakarta \\ E-mail:d'art_ono@aau.ac.id,holimin@aau.ac.id,djoko_prihantoro@aau.ac.id
}

\begin{abstract}
In the Era of Society 5.0., when the threat of the existence of the nation state became increasingly complex, Indonesian nationalism indicated a decline. The degradation of the role of the family and society has had an impact on the role of education which until now has not been effective enough. This literature study aims to explain the condition of Indonesian nationalism, family and society as the dominant factor, and how to revitalize the role of education stakeholders in the develop-ment of nationalism in Era 5.0. By applying the descriptive-qualitative method the study concludes; (1) the construction of Indonesian nationalism is built on a strong foundation of perception and belief in colonialism as an external threat (common enemy) to the existence of the nation-state which continues to dominate the journey of national life until the Era of Society 5.0, and therefore contextualization of perceptions and beliefs is absolutely necessary, (2) the role of the unity of fate tends to stagnate along with the widening of various gaps in national life. The role of education also decreases along with the degradation of the role of family and society, (3) reempowerment of the role of family and society is very vital in order to build perceptions and beliefs of all elements of society in understanding the counter ideology of Pancasila, the flood of foreign products, and others as threats (common enemies) the existence of the nation state. For this reason, the presence of relevant government policies, empowerment of institutions or organizations that have direct access to the society, as well as implementation and control mechanisms, and measurable evaluations are needed to continuously improve the effectiveness of their implementation.
\end{abstract}

Keywords— Nationalism Education, Era Society 5.0., Revitalization, Role of Family and Society

Abstrak- Di Era Society 5.0., di saat ancaman eksistensi negara bangsa kian kompleks, nasionalisme Indonesia terindikasi menurun. Terjadinya degradasi peran keluarga dan masyarakat telah berdampak pada peran pendidikan yang hingga kini belum cukup efektif. Studi literatur ini bertujuan untuk menjelaskan tentang kondisi nasionalisme Indonesia, keluarga dan masyarakat sebagai faktor dominan, serta bagaimana merevitalisasi peran stakeholders pendidikan dalam pembangunan nasionalisme di Era Society 5.0. Dengan menerapkan metode deskriptif-kualitatif studi menyimpulkan; (1) konstruksi nasionalisme Indonesia terbangun di atas pondasi persepsi dan keyakinan yang kuat atas kolonialisme sebagai ancaman luar (musuh bersama) terhadap eksistensi nation-state yang terus mendominasi perjalanan kehidupan kebangsaan hingga Era Society 5.0, dan oleh karenanya kontekstualisasi persepsi dan keyakinan mutlak dilakukan, (2) peran kesatuan nasib cenderung stagnan seiring melebarnya berbagai kesenjangan dalam kehidupan nasional. Peran pendidikan juga menurun seiring terjadinya degradasi peran keluarga dan masyarakat, (3)

\footnotetext{
*Penulis Korespondensi (Dartono)
}

E-mail:d'art_ono@aau.ac.id 
pemberdayaan kembali peran keluarga dan masyarakat sangat vital guna membangun persepsi dan keyakinan seluruh elemen masyarakat akan faham kontra ideologi Pancasila, membanjirnya produk asing, dan lain-lain sebagai ancaman (musuh bersama) eksistensi negara bangsa. Untuk itu kehadiran kebijakan yang relevan, pemberdayaan lembaga ataupun organisasi yang memiliki akses langsung terhadap masyarakat, serta mekanisme pelaksanaan, mekanisme kontrol, dan evaluasi secara terukur sangat diperlukan untuk terus meningkatkan efektivitas pelaksanaannya.

Kata Kunci- Pendidikan Nasionalisme, Era Society 5.0., Revitalisasi Peran Keluarga dan Masyarakat

\section{Pendahuluan}

$\mathrm{K}$ etika di akhir abad ke-20 Uni Soviet (1991) terpecah menjadi 15 negara dunia sangat terkejut, diikuti terpecahnya Yugoslavia (2003) menjadi tujuh negara. Sulit menepis keberadaan pengaruh eksternal, akan tetapi problem utamanya ialah internal yaitu nasionalisme. Ada persoalan dalam pembangunan nasionalisme di kedua negara[1],[2]. Flash back ke era pasca Perang Dunia ke-II, kelahiran beberapa negara dunia ketiga termasuk Indonesia juga tidak terlepas dari konteks nasionalisme. Fakta ini cukup menegaskan betapa nasionalisme menjadi prasyarat mutlak bagi eksistensi suatu negara bangsa (nation state). Dalam catatan Sejarawan Arnold Toynbee misalnya, "dari 21 peradaban dunia yang tercatat, 19 diantaranya hancur bukan karena penaklukan dari luar, akan tetapi karena pembusukan moral dari dalam"'[3, p. 16]. Suatu fenomena yang sangat kontras dimana pakar Hukum Humaniter Jean Pictet mencatat, "suatu kenyataan menyedihkan, selama 3400 tahun sejarah tertulis, umat manusia hanya mengenal 250 tahun masa damai"'[4, p. 295]. Demikian juga catatan T. Jacob bahwa, dalam 5600 tahun terakhir manusia telah menggelar 14.600 perang[5, p. 9]. Perang tampak telah menjadi "tradisi" mempertahankan diri dalam relasi antar-manusia dan antar-bangsa, meskipun kekalahan tidak identik petaka eksistensi negara-bangsa. Pasca kekalahan pada Perang Dunia misalnya, Jerman dan Jepang kini menjadi negara termaju.

Di Indonesia, nasionalisme yang diawali kelahiran Boedi Oetomo (20 Mei 1908) terus mengkristal hingga pelaksanaan Kongres Pemuda (28 Oktober 1928), dan mencapai puncaknya pada proklamasi 17 Agustus 1945. Namun di era sesudahnya ada persoalan sangat kompleks terkait nasionalisme Indonesia. Tidak sampai meruntuhkan, akan tetapi berbagai konflik internal yang mengemuka telah menjadi ancaman yang sangat serius bagi nation-state Indonesia. Sebut saja aksi separatis RMS (1950), PRRI/Permesta (1957), GAM (mulai 1976), Timor Timur (1999) yang kini menjadi Negara Timor Leste, dan hingga kini OPM, serta aksi kontra ideologi Pancasila seperti DI/TII (1950-1960-an) serta PKI (1948 dan 1965). Bahkan konflik bernuansa Suku, Agama, Ras, dan Antar-golongan (SARA) sebagaimana terjadi di Ambon (1999) dan Sampit (2001) justeru terjadi di awal era reformasi. Azyumardi Azra mencatat bahwa, selama tiga tahun era reformasi, Indonesia tidak hanya gagal mengatasi krisis ekonomi dan politik, akan tetapi lebih mengerikan lagi, berada dalam disintegrasi sosial-politik baik secara vertikal maupun horizontal[6, p. 172]. Artinya memang ada persoalan yang sangat serius dalam konteks pembangunan nasionalisme di Indonesia.

Di era society 5.0. dengan salah satu karakteristik utamanya penggunaan teknologi informasi (IT) yang kian masif, tentu banyak hal positif, akan tetapi berbagai permasalahan baru yang kompleks juga mengemuka. Berbagai faham kontra ideologi Pancasila, ujaran kebencian (hate speech), berita bohong (hoax), dan konten bernuansa Suku, Agama, Ras, dan Antar Golongan (SARA) kian menjadi "menu harian" bagi pengguna media sosial. Bila dicermati mendalam, betapa indikasi polarisasi bangsa ini telah demikian nyata. Doni Koesoema mencatat bahwa, dewasa ini manusia dihadapkan pada hegemoni media, revolusi Iptek, yang tidak hanya melahirkan kemudahan dan perubahan positif, akan tetapi mengundang banyak kekhawatiran[7, p. 115]. Peran sekolah juga dipandang belum cukup efektif, Wibowo menguraikannya, serta Russell dan Ratna bahwa mata ajaran seperti Pendidikan Kewarganegaraan (PKn) misalnya. 
masih sebatas teori[8, p. 106]. Pada sisi lain peran keluarga juga kian terdegradasi. Nurmila dan Ratnawaty misalnya mencatat bahwa, "wanita bekerja di Dusun Sawagi Kecamatan Pattallassang memiliki waktu rendah untuk mendidik anaknya"[9]. Dampaknya ada kecenderungan orang tua "memasrahkan" peran mendidik anak-anak mereka kepada sekolah (guru). Logis bila kemudian karakter bangsa pun terus terdegradasi. Oleh karenanya Daradjat berpesan agar orang tua tidak membiarkan anak-anak mereka tumbuh tanpa bimbingan (diserahkan) kepada guru atau sekolah. Ini kekeliruan fatal yang banyak terjadi di masyarakat[10, p. 47]. Untuk itu di Era Society 5.0., revitalisasi peran keluarga dan masyarakat dapat menjadi alternatif solusi dalam mengefektifkan pendidikan nasionalisme di Indonesia.

\section{LANDASAN TEORI}

\section{A. Nasionalisme dan Pendidikan Nilai}

Belum ada konsep baku, Kamus Besar Bahasa Indonesia (KBBI) misalnya menguraikan makna nasionalisme (nationlism) sebagai paham atau ajaran untuk mencintai bangsa dan negara sendiri[11]. Kemudian Hans Kohn memaknai nasionalisme sebagai kesetiaan tertinggi seseorang diberikan kepada negara kebangsaan[12, p. 11]. Sementara menurut Ernest Renan, terdapat dua makna nasionalisme sebagaimana statement-nya:

"A nation is a soul, a spiritual principle. Two things, which strictly speaking are just one, constitute this soul, this spiritual principle. One is in the past, the other in the present. One is the common possession of a rich legacy of memories; the other is actual consent, the desire to live together, the will to continue to value the heritage that has been received in common" [13, pp. 57-58]

Tiga nilai setidaknya dapat dipetik dari pengertian nasionalisme di atas yaitu cinta tanah air, kesetiaan kepada negara, dan tekad bersatu sebagai bangsa. Ketiganya berorientasi pada prinsip eksistensi nation-state. Otto Bauer dalam bukunya Die Nationalitatenfrage, menjelaskan bahwa nasionalisme adalah "eine nation ist eine aus chiksalgemeinschaft erwachsene charactergemeinschaft" (kesatuan perangai yang timbul karena kesatuan nasib)[14]. Dengan demikian nasionalisme dapat dimaknai sebagai kesamaan karakter, manifestasi rasa cinta, loyalitas, dan tekad bersatu sebagai bangsa. Oleh sebab itu spektrum implementasinya menjadi sangat luas. Sementara Aman menyebut adanya 6 indikator sikap nasionalisme yaitu bangga menjadi bangsa Indonesia, cinta tanah air dan bangsa, rela berkorban bagi bangsa, toleransi, bangga pada budaya yang beragam, menghargai jasa pahlawan, dan peduli sosial[7, p. 37]. Uraian tersebut cukup mengarah pada pemahaman bahwa nasionalisme memiliki keterkaitan yang sangat erat dengan konteks karakter secara keseluruhan.

Menurut ahli psikologi Gordon Allport dalam Kuperman (1983), nilai adalah keyakinan yang membuat seseorang melakukan tindakan atas dasar pilihannya. Nilai merupakan patokan normatif yang memengaruhi manusia dalam menentukan pilihannya di antara berbagai cara tindakan alternatif $[15$, p. 62]. Tersedia cukup banyak konsep, akan tetapi secara umum ada tiga klasifikasi teori pendidikan nilai. Elias misalnya, mengklasifikasikan berbagai teori yang berkembang menjadi tiga, yakni: pendekatan kognitif, pendekatan afektif, dan pendekatan perilaku. Sementara klasifikasi menurut Rest didasarkan pada tiga unsur moralitas, yang biasa menjadi tumpuan kajian psikologi, yakni: perilaku, kognisi, dan afeksi[16]. Sejalan hal tersebut, pakar pendidikan nilai, Hill dalam Adisusilo menguraikan bahwa, "sebagai acuan perilaku, nilai meliputi tiga tahapan yaitu nilai yang dipikirkan (value thinking atau value cognitive), nilai sebagai kepercayaan atau keyakinan (niat) untuk melakukan sesuatu (value affective), dan nilai yang telah mewujud menjadi tindakan nyata (value action), yaitu nilai terkait keyakinan dijadikan sebagai acuan dalam bersikap-berperilaku sesuai moralitas yang berlaku di dalam masyarakat". Ini menunjukkan bahwa penanaman nilai agar masyarakat memahami arah kehidupan mutlak dilakukan sejak dini. Semantara terkait pendidikan nilai, Thapar juga dalam 
Adisusilo menyatakan bahwa, "value education is education in value and education towards the inculcation of value". Lebih lanjut Hill menjelaskan bahwa nilai harus membuat manusia mampu menguasai pengetahuan yang berakar pada nilai-nilai tradisionalnya guna menghadapi nilai-nilai modern; memiliki empati dengan persepsi dan perasaan orang-orang yang tradisional; mengembangkan keterampilan kritis dan menghargai nilai-nilai itu; mengembangkan diri agar terampil membuat keputusan dan berdialog dengan sesama; dan akhirnya mampu mendorong manusia untuk berkomitmen kepada masyarakat dan warganya. Jadi pendidikan nilai bukan sekadar ditambahkan, akan tetapi sesuatu yang hakiki dalam seluruh proses pendidikan di lembaga sosial terutama keluarga. Pendidikan nilai tidak serta merta terjadi dalam diri seseorang, tetapi bersifat prosesual, dimana tujuan pendidikan nilai dapat terlihat hanya jika setiap tahapan pendidikan nilai dapat tercapai[17].

\section{B. Peran Keluarga dan Masyarakat}

Arie Budhiman, Staf Ahli Kementerian Pendidikan dan Kebudayaan Bidang Pengembangan Karakter menyatakan bahwa "guru, keluarga, dan masyarakat, harus saling bekerja sama dalam penguatan pendidikan karakter"'[18]. Statement ini merujuk pada konsep Tri Pusat Pendidikan, dimana Ki Hadjar Dewantara (Bapak Pendidikan Indonesia) menekankan tentang adanya tiga komponen yang memiliki peran strategis dalam membentuk karakter yaitu keluarga, sekolah, dan masyarakat[19]. Statement itu juga selaras dengan Langeveld (dalam Tirtahardjha) yang menyatakan bahwa keluarga, sekolah, dan masyarakat memiliki tanggung jawab terhadap pendidikan[18]. Keluarga khususnya orang tua merupakan tempat sosialisasi bagi anak-anak tentang peradaban dan berbagai hal di dalamnya, seperti nilai-nilai sosial, tradisi, keterampilan, prinsip, dan pola perilaku dalam segala aspek. Keluarga mutlak berperan sebagai sarana pendidik dan pemberian nilai-nilai budaya yang mendasar dalam kehidupan anak. Untuk itu, keluarga (orang tua) harus membekali anak-anak mereka dengan nilai-nilai yang berlaku di dalam masyarakat[17], termasuk nasionalisme tentunya. Menurut Melly Latifah, keluarga adalah pusat pendidikan pertama dan terpenting. Keberhasilan pendidikan di dalam lingkup keluarga akan memuluskan pendidikan pada lingkup selanjutnya. Sebaliknya, kegagalan pendidikan di dalam lingkup keluarga akan menyulitkan institusi di luar keluarga (termasuk sekolah) untuk memperbaiki kegagalan itu[8]

Dalam hal peran masyarakat, Shofwan menguraikan bahwa pendidikan lingkup masyarakat dapat menjadi pengganti, pelengkap, sekaligus penambah, dan mungkin pengembangan pendidikan di dalam lingkup keluarga dan sekolah[20]. Sesuai konsep Tri Pusat Pendidikan, masyarakat mencakup elemen selain keluarga dan sekolah[19], dan oleh karenanya cakupannya cukup luas. Sementara konsep Howard Wriggins menjelasakan bahwa pemimpin sebagai personifikasi bangsa memiliki peran signifikan bagi peningkatan integrasi nasional. Demikian juga lembaga politik dan administrasi seperti birokrasi, tentara, media, parpol, dan legislatif dalam menciptakan identitas bangsa mutlak menjembatani konflik untuk kepentingan bersama[21]. Oleh sebab itu beberapa elemen sebagaimana disebut Wriggins di atas dapat dikategori sebagai masyarakat. Menurut Shihab, situasi kemasyarakatan dengan sistem nilai yang dianutnya, mempengaruhi sikap dan cara pandang masyarakat secara keseluruhan. Jika sistem nilai dan pandangan mereka terbatas pada "kini dan di sini", maka upaya dan ambisinya terbatas pada kini dan di sini pula[22]. Dengan demikian kian jelas urgensi pemberdayaan peran masyarakat dalam membangun karakter bangsa khususnya nasionalisme.

\section{ERA SOCIETy DAN BEBERAPA CATATAN KePRIHATINAN}

Bung Karno pernah menyatakan, "perjuanganku lebih mudah karena melawan penjajah, namun perjuangan kalian akan lebih sulit karena melawan bangsa sendiri"[23]. Dua hal 
setidaknya tersirat dari statement tersebut yaitu pertama, pasca pengakuan kedaulatan (27 Desember 1949) ancaman terhadap eksistensi NKRI akan lebih dominan berasal dari dalam. Kalaupun berasal dari luar, maka ia akan "meminjam tangan-tangan dari dalam". Gerakan separatis RMS (1950) di Maluku, PRRI/Permesta (1957) di Sumatera dan Sulawesi, GAM (mulai 1976) di Aceh, Timor-Timur pisah (1999), dan hingga kini OPM di Papua, serta gerakan kontra ideologi Pancasila seperti DI/TII (1950-1960-an) di Jawa Barat, Jawa Tengah, Sulawesi Selatan, dan Aceh dan PKI (1948 dan 1965) memang merupakan problem internal, akan tetapi terbukti sarat kepentingan asing[24]. Kedua, banyak oknum warga negara yang alih-alih berkorban, mereka justeru memiliki sikap dan perilaku merusak, menggerogoti, dan bahkan menghancurkan negara. Jurnalis sekaligus budayawan Mochtar Lubis pada tanggal 6 April 1977 menyampaikan sebuah pidato kebudayaan di Taman Ismail Marzuki yang kemudian dibukukan pada tahun 1990 dengan judul yang sama, "Manusia Indonesia". Dalam catatannya orang Indonesia memiliki ciri-ciri munafik (hipokrit), enggan bertanggung jawab, memiliki jiwa feodal, percaya takhyul, artistik, dan berwatak lemah[25]. Sri Hajati dan Ahmad Yani memaknai sifat munafik sebagai berpura-pura, lain di muka lain di belakang, dan tampak masih menggejala pada wajah kita. Berkaitan dengan isu korupsi misalnya, semua mengutuk korupsi, akan tetapi terus saja melakukan korupsi dan dari kehari korupsi kian bertambah besar saja[26, pp. 168-169]. Dua dekade kemudian, Eep Saefulloh Fatah dalam bukunya, Bangsaku yang Menyebalkan[27] dan penyair Taufiq Ismail dalam kumpulan puisi karyanya, Malu (Aku) Jadi Orang Indonesia[28] mencatatkan hal yang kurang lebih serupa.

Dalam kehidupan keseharian, mengemuka rasa jengkel atas terjadinya berbagai pelanggaran lalu lintas sebagai biang kemacetan, dan bahkan kecelakaan (accident), akan tetapi banyak yang justeru menjadi bagian darinya. Aktif menggaungkan cinta produk dalam negeri (lokal), akan tetapi justeru berbangga terhadap produk impor. Oleh sebab itu ajakan Mochtar Lubis, Eep Saifulloh Fatah, dan Taufik Ismail untuk kembali kepada jatidiri ke-Indonesia-an di atas kiranya akan tetap relevan hingga kini dan di masa mendatang. Demikian juga catatan Gunnar Myrdal dalam The Challenge of World Poverty yang mengkategori Indonesia sebagai Negara lembek (soft state) cukup argumentatif. Menurut catatannya orang Indonesia memiliki adab atau karsa yang lemah (tidak taat terhadap hukum, aturan, dan norma, serta berperilaku tidak disiplin)[29]. Era reformasi (dimulai 1998) yang digadang akan membawa perubahan, ternyata potret tersebut tidak kunjung menunjukkan perbaikan. Seperti telah terurai, Azyumardi Azra menyatakan bahwa, "dalam perjalanan tiga tahun era reformasi, Indonesia tidak hanya gagal mengatasi krisis ekonomi dan politik, akan tetapi lebih mengerikan lagi, berada dalam disintegrasi sosial dan politik baik secara vertikal maupun horizontal". Tidak heran bila sebagian besar orang yang diwawancara Harian The Jakarta Post (20 Mei 2001) mengaku tidak lagi bangga sebagai orang Indonesia (having no pride as Indonesian)[6]. Hill menekankan bahwa nilai harus mampu membuat manusia menguasai pengetahuan yang berakar pada nilainilai tradisionalnya guna menghadapi nilai-nilai modern serta mampu mendorong manusia memiliki komitmen pada masyarakat dan warganya[30, pp. 70-71]. Oleh sebab itu nasionalisme sebagai nilai dan idealisme akan tetap relevan di segala jaman termasuk dalam menghadapi berbagai dampak modernitas yang mengemuka di era society 5.0. Dengan demikian berbagai ekspresi keprihatinan beberapa tokoh sperti terurai di atas, patut dimaknai sebagai ajakan ataupun himbauan untuk segera kembali kepada jati diri ke-Indonesia-an.

Dalam masa tiga tahun lalu (2017 - 2019) data hasil survei yang dikeluarkan oleh Lembaga Survei Indonesia (LSI) menunjukkan tren indikasi positif. Direktur Eksekutif LSI Djayadi Hanan menyebutkan bahwa pada tahun 2017, 58,5 persen warga lebih senang mendudukkan diri sebagai warga Negara Indonesia (WNI) ketimbang identitas suku ataupun agama. Kemudian pada tahun 2018 angkanya meningkat menjadi 61,4 persen, dan pada tahun 2019 kembali meningkat menjadi 66,4 persen[31]. Tentu ini positif, akan tetapi sikap perilaku yang merupakan ekspresi (implementasi) nilai-nilai nasionalisme (cinta tanah air, kesetiaan kepada negara, dan tekad bersatu sebagai bangsa) juga tidak kalah penting. Secara faktual, Marley mencatat bahwa kesadaran sebagai masyarakat Indonesia baik di pusat maupuan di daerah masih bermasalah. Berbagai peristiwa di banyak daerah seperti lemahnya penegakan hukum, konflik antar partai, korupsi yang merajalela, tawuran antar-pelajar dan kampung, kekerasan 
dalam keluarga dan sekolah, narkoba, intoleransi beragama, ancaman teroris, dan masih adanya gerakan pemisahan diri di beberapa daerah di Indonesia menjadi indikasi[32]. Merespon berbagai fenomena tersebut, Presiden Joko Widodo di awal masa jabatannya pun mengekspresikan kegundahan melalui statement-nya, "saya juga ndak tahu kenapa, sedikit demi sedikit (karakter) itu berubah dan kita ndak sadar. Yang lebih parah lagi ndak ada yang ngerem. Yang seperti itulah yang merusak mental"[33]. Sementara terpecahnya negara adidaya Uni Soviet (1991) menjadi 15 negara (Rusia, Armenia, Azerbaijan, Belarus, Turkmenistan, Estonia, Georgia, Kazakhstan, Kirgistan, Uzbekistan, Lithuania, Moldova, Tajikistan, Ukraina, dan Latvia), diikuti Yugoslavia (2003) yang terpecah menjadi tujuh negara (Slovenia, Makedonia, Montenegro, Serbia, Kroasia, Bosnia-Herzegovina, dan Kosovo), dapat menjadi sinyalemen betapa di era society 5.0., tanpa nasionalisme yang kuat tidak satupun negara steril dari potensi ancaman keruntuhan. Oleh sebab itu bila kondisi nasionalisme masyarakat Indonesia tidak juga kunjung membaik, maka nation-state Indonesia memiliki potensi termasuk dalam catatan Arnold Toynbee bahwa "dari 21 peradaban dunia yang tercatat, 19 diantaranya hancur bukan karena penaklukan dari luar, akan tetapi karena pembusukan moral dari dalam"[3]. Untuk itu pemberdayaan seluruh stidakeholders menjadi kata kunci agar statement Philip Guedalla (18891944), l'histoire se répète[34], tidak terjadi di nation-state Indonesia.

\section{Memberdayakan Kembali Peran Keluarga Dan MasyaraKat}

\section{A. Pasang Surut Nasionalisme Indonesia}

Wriggins menyatakan, keberadaan ancaman luar (musuh bersama) memiliki kontribusi yang besar bagi peningkatan integrasi bangsa[21]. Oleh sebab itu cukup relevan, kebangkitan dan penguatan nasionalisme Indonesia tidak terpisahkan dengan konteks kolonialisme (penjajahan) khususnya Belanda sebagai ancaman luar (musuh bersama). Ia tidak beranjak, bahkan pada saat ancaman atas eksistensi negara-bangsa telah bergeser dan semakin kompleks. Pasca pengakuan kedaulatan, konfrontasi dengan Malaysia (1963) misalnya, semakin menegaskan sinyalemen tersebut. Jargon yang digaungkan Bung Karno, "Ganyang Malaysia", merupakan reaksi atas pembentukan Negara Federasi Malaysia yang dipandang sebagai ancaman, representasi kepentingan neo-kolonialisme Inggris dan sekutunya[35, p. 3]. Demikian pula klaim wilayah seperti atas blok Ambalat, dimana sesuai peta wilayah tahun 1973, Malaysia beranggapan bahwa masuknya Sipadan dan Ligitan sebagai kedaulatan, otomatis perairan laut tersebut masuk kedalam garis wilayah mereka[36]. Reaksi pun bermunculan, dimana selama periode 2005 hingga 2010 masyarakat Indonesia beramai-ramai membentuk Posko Ganyang Malaysia[37].

Dihadapkan dengan perspektif Hill, maka nasionalisme Indonesia yang mengacu catatan Wriggins tidak terpisahkan dengan keberadaan ancaman fisik-militer sebagai acuan dalam berperilaku telah melampaui tahapan persepsi (value thinking atau value cognitive), keyakinan (value affective), dan tindakan (value action). Sementara berbagai ancaman yang lebih aktual seperti membanjirnya produk asing yang sesungguhnya juga tidak kalah destruktif bahkan lebih permanen, di mana presiden Jokowi meresponnya dengan menggaungkan jargon "benci produk asing" baru-baru ini misalnya[38], minim respon publik, demikian juga terkait keberadaan berbagai faham kontra ideologi Pancasila (seperti materialisme, individualisme, liberalisme, komunisme, terorisme, dan lain-lain). Demikian juga penyebaran gaya hidup (life style) hedon dan western yang kian menjadi trend dalam masyarakat. Hal tersebut menjadi indikasi belum terlampauinya seluruh tahapan pendidikan nilai, atau setidaknya tahapan value thinking dan value affective atas berbagai fenomena tersebut sebagai ancaman (musuh) bersama. Ekspresi nasionalisme Indonesia pun cenderung stag pada konteks ancaman tradisional (fisik-militer) yang bersifat sporadis-insidensial. Nasionalisme model demikian tidak permanen dan cenderung bersifat sesaat (temporary). Meminjam istilah Fajlur Rahman, ketua Lembaga Pengkajian Demokrasi dan Negara bahwa, "nasionalisme yang muncul dalam merespon isu Malaysia 
merupakan nasionalisme reaktif, padahal lebih dari itu, nasionalisme ekonomi justeru lebih penting"[39].

\section{B. Beberapa Faktor Dominan}

Pendidikan nilai tidak begitu saja terjadi pada diri seseorang, akan tetapi merupakan proses sepanjang hayat. Tujuannya akan dapat terlihat hanya apabila setiap tahapan di dalamnya dapat terlampaui. Dalam perspektif moralitas Durkheim (dalam Ritzer), "menanamkan nilai moralitas bukan melalui khotbah atau indoktrinasi, akan tetapi menjelaskan. Jika kita menolak memberikan semua penjelasan tersebut kepada anak-anak, jika kita tidak mencoba membantu mereka memahami alasan-alasan yang melatarbelakangi mengapa aturan-aturan perlu dipatuhi, kita akan menyalahkan mereka sebagai orang-orang yang memiliki moralitas yang tidak lengkap dan inferior"[17]. Oleh sebab itu menjadi keharusan dalam pendidikan nilai untuk dapat melampaui setiap tahapan pendidikan kepada seluruh elemen masyarakat.

Secara historis penetapan etische politiek (1901) oleh Belanda telah mendorong kebangkitan nasionalisme kaum terpelajar[40, p. 191]. Dalam hal ini pendidikan telah mengakselerasi proses kebangkitan dan penguatan nasionalisme Indonesia. Hanya tujuh tahun dibutuhkan bagi pendidikan untuk menuju kebangkitan nasional (1908) dan 44 tahun menuju proklamasi kemerdekaan (17 Agustus 1945). Sementara di era sebelumnya, sejak kedatangan Cornelis de Houtman (1596) di Banten dibutuhkan hingga tiga abad lebih menuju kebangkitan nasional dan tiga setengah abad menuju kemerdekaan, dan sejak era kolonialisme pasca Vereenigde Oostindische Compagnie (VOC, 1799), dibutuhkan waktu satu abad lebih menuju kebangkitan nasional dan hampir satu setengah abad menuju kemerdekaan. Sesuai perspektif Thapar bahwa, "value education is education in value and education towards the inculcation of value", dan perspektif Hill bahwa "pendidikan nilai pada akhirnya harus mampu mendorong manusia berkomitmen pada masyarakat dan warganya" seperti telah terurai di atas, maka akumulasi peran pendidikan, ancaman (musuh) bersama, dan kesatuan nasib (chicksalgemeinschaft) di era kolonial telah mampu membangkitkan dan menguatkan nasionalisme Indonesia pada jamannya.

Ekonomi (kesejahteraan) juga tidak boleh diabaikan. Wriggins menyatakan bahwa, perluasan kesempatan dan pembangunan ekonomi untuk kesejahteraan bersama memiliki kontribusi yang juga signifikan bagi penguatan integrasi nasional[21]. Secara faktual berbagai pemberontakan yang terjadi di Indonesia, menjadikan isu kesejahteraan sebagai media yang cukup efektif dalam mendiskreditasi pemerintah sekaligus menarik simpati masyarakat. Akan tetapi perlu dicatat bahwa pada saat pembentukan Negara Federasi Malaysia misalnya, tanpa hirau situasi dan kondisi kesejahteraan, masyarakat serentak merespon secara spontan[37]. Artinya, penekanan Wriggins lebih pada soal kesejahteraan bersama atau kesatuan nasib sebagaimana pengertian nasionalisme Bauer. Dengan demikian semua bentuk sikap perilaku yang mencederai prinsip kesatuan nasib (chiksalgemeinschaft) seperti korupsi, kolusi, dan nepotisme, diskriminasi, marjinalisasi terhadap kelompok tertentu dan lain-lain akan menjadi "duri" bagi pembangunan nasionalisme. Itu mutlak dihindari, terlebih oleh para elite negeri ataupun elite lembaga politik dan administrasi yang seharusnya menjadi jembatan atas terjadinya konflik untuk kepentingan bersama seperti catatan Wriggins. Sementara berbagai bentuk kebijakan (policy) ataupun upaya dengan proyeksi mempersempit kesenjangan (gap) seperti pemerataan pembangunan, dapat menjadi media pendorong yang cukup efektif. Masyarakat sendiri dapat berperan langsung antara lain dengan memberikan prioritas untuk menggunakan produk lokal (dalam negeri) yang baik secara langsung maupun tidak langsung akan berkontribusi menyerap tenaga kerja dan lebih jauh terhadap pemerataan ekonomi. Namun demikian, muaranya akan kembali pada persoalan apakah membanjirnya produk impor sebagai ancaman luar telah melampaui tahapan persepsi dan keyakinan masyarakat. Untuk itu sosialisasi dan internalisasi secara berkelanjutan kepada masyarakat menjadi prioritas untuk segera dilakukan. 


\section{Memberdayakan Peran Keluarga dan Masyarakat}

Hingga memasuki Era Society 5.0., peran pendidikan nilai dalam hal ini nasionalisme dipandang belum cukup efektif. Ki Hadjar Dewantara melalui konsep Tri Pusat Pendidikan sejak awal telah menekankan peran strategis keluarga dan masyarakat. Kedua elemen tersebut harus dapat harmonis bersinergi dengan sekolah[19]. Dalam perspektif tradisional, mendidik anak memang menjadi domain keluarga (orang tua), akan tetapi peningkatan aktivitas para ibu yang kian padat, telah berdampak terjadinya degradasi peran keluarga. Hasil kajian Kusumawati tentang "Peran Ganda Perempuan Pemetik Teh"[41], serta Nurmila dan Ratnawati tentang "Analisis Perhatian Wanita Karir terhadap Keberhasilan Anak dalam Keluarga di Dusun sawagi Kecamatan Patallassang Kabupaten Gowa"[9], menunjukkan hal tersebut. Relevan bila banyak orang tua "memasrahkan" peran mendidik anak-anak mereka kepada sekolah (guru). Namun pada saat guru mengambil peran itu, seperti menghukum untuk mendidik, orang tua siswa justeru resisten. Berbagai sikap ataupun tindakan negatif hingga pelaporan kepada aparat harus diterima para guru. Harian Republika mencatat, "tidak sedikit orang tua marah saat anaknya dihukum oleh guru terlebih bila hukumannya tidak sesuai kebiasaan keluarga. Misal, anak mendapat hukuman fisik, seperti dijewer, dibentak, atau disindir dengan kata-kata kasar[42]. Logis bila kemudian dalam hal ini para guru pun cenderung bersikap masa bodoh, dan pola relasi yang terbangun antara guru-siswa pada akhirnya cenderung bersifat transaksional.

Tidak sedikit juga orang tua yang menampilkan "wajah" kontradiktif dengan kebijakan atau aturan yang berlaku di sekolah. Dalam keseharian banyak orang tua yang memfasilitasi anakanak mereka yang belum cukup umur dengan sepeda motor atau handphone berfitur canggih misalnya, serta memanjakan mereka dengan berbagai properti import berharga mahal. Terkait fenomena tersebut Sukardi dalam "Pendidikan Nilai Mengatasi Degradasi Moral Keluarga" bahkan mencatat, kondisi keluarga sebagai lembaga sosial yang berpengaruh besar terhadap cita-cita suatu bangsa, memiliki tugas menanamkan nilai dan moral yang berlaku di dalam masyarakat sejak dini kepada anak sangat memprihatinkan. Sebagian keluarga kurang memperhatikan nilai-nilai moral di dalam setiap perbuatan yang mereka lakukan, bahkan sebagian besar keluarga di kota-kota besar telah melakukan tindakan penyimpangan. Hal serupa diungkapkan Latifah bahwa, "keluarga merupakan lembaga pendidikan lingkup pertama dan utama, karena keberhasilan pendidikan karakter di dalam keluarga akan memuluskan pendidikan karakter pada lingkup selanjutnya. Sebaliknya, kegagalan pendidikan karakter dalam keluarga akan menyulitkan institusi-institusi lain di luar keluarga (termasuk sekolah) untuk memperbaiki kegagalan tersebut'[8]. Cukup jelas, pendidikan nilai sangat mendasar khususnya dalam keluarga. Logis bila pendidikan nilai/karakter di sekolah juga tidak cukup efektif. Fakta pendidikan nasionalisme yang tidak terpisahkan dari pendidikan karakter/nilai pada umumnya, maka nyaris mustahil membangun nasionalisme tanpa pemberdayaan kembali peran keluarga.

Masyarakat sebagaimana konsep Tri Pusat Pendidikan, juga memiliki peran strategis. Boedi Oetomo (1908), diikuti organisasi pergerakan lainnya dibentuk sebelum nation-state (Indonesia) eksis. Masyarakat menjadi inisiator. Seperti telah terurai, pendidikan lingkup masyarakat dapat menjadi pengganti, pelengkap, serta penambah, bahkan pengembangan pendidikan lingkup keluarga dan sekolah[20]. Masyarakat merupakan kancah bagi setiap individu untuk aktif beraktualisasi mengembangkan potensi diri, serta tempat berlatih membentuk watak (karakter). Namun menurut Purwaningsih, degradasi moral telah melanda semua kalangan masyarakat, dari anak-anak hingga dewasa, bahkan telah memasuki semua lembaga sosial-masyarakat[43], dan tentu ini menjadi persoalan. Sementara menurut Hadis dan Nurhayati, salah satu sebab merosotnya mutu pendidikan ialah kurang memaksimalkan komunikasi dan informasi dalam dunia pendidikan termasuk menjalin hubungan baik dengan masyarakat[44]. Oleh karenanya keberadaan pemimpin serta lembaga politik dan administrasi (birokrasi, tentara, media, parpol, dan legislatif) dalam menciptakan identitas bangsa yang menjembatani konflik untuk kepentingan bersama sebagaimana catatan Wriggins akan dapat mengakumulasi peran masyarakat. Quraish Shihab menyatakan, peran masyarakat dalam pendidikan terkait erat dengan pengubahan cara pandang mereka terhadap pendidikan. Tentu bukan hal mudah, akan 
tetapi bila tidak dimulai dari sekarang, rasa memiliki, kepedulian, keterlibatan, dan peran aktif masyarakat dengan tingkatan maksimal dapat diperolah dunia pendidikan[21]? Sebagai pendidik, menjadi keharusan bagi keluarga (orang tua) dan masyarakat untuk mengetahui dan memahami nilai-nilai apa yang akan mereka ajarkan. Notonagoro dalam Atmaji dan Setiyaningsih mengajukan empat langkah yang harus ditempuh, dan sebagai langkah pertama, pendidik terlebih dahulu harus tahu dan memahami nilai-nilai apa saja yang diajarkan tentang yang tersembunyi dibalik setiap studi atau nilai-nilai kemanusiaan lainnya[16].

Di samping pemahaman konsep kepemimpinan dan penguasaan teknik (tools) softskill yang relevan, keteladanan mutlak bagi pemimpin. Ki Hadjar Dewantara sejak awal telah menekankan melalui konsepnya, ing ngarsa sung tuladha. Sementara dalam catatan Wriggins, penampilan (performance) pemimpin sebagai personifikasi bangsa (seluruh entitas yang dipimpin) menjadi keniscayaan. Ini cermin bahwa pemimpin menjadi milik sekaligus mengayomi semua elemen yang dipimpinnya. Karenanya kebijakan (policy) yang lahir juga mutlak bersifat populis dan selalu berorientasi pada negara dan bangsa. Demikian juga mas-media memiliki peran penting. Namun perlu dicatat, terdapat tren jurnalisme negatif yang menjadi titik dimana media massa dapat mempengaruhi opini publik. Berita-berita seputar korupsi, kericuhan politik, kriminal, bencana alam, dan sebagainya menjadi komoditas bagi industri media massa. Seperti dicatat oleh Jhon Tierney dalam the New York Times edisi 13 Maret 2013, bahwa pandangan umum dalam dunia jurnalistik ialah "bad news sells" (semakin berdarah, semakin bernilai)[45]. Efektivitas menjadi hal utama, namun efisiensi juga mutlak.

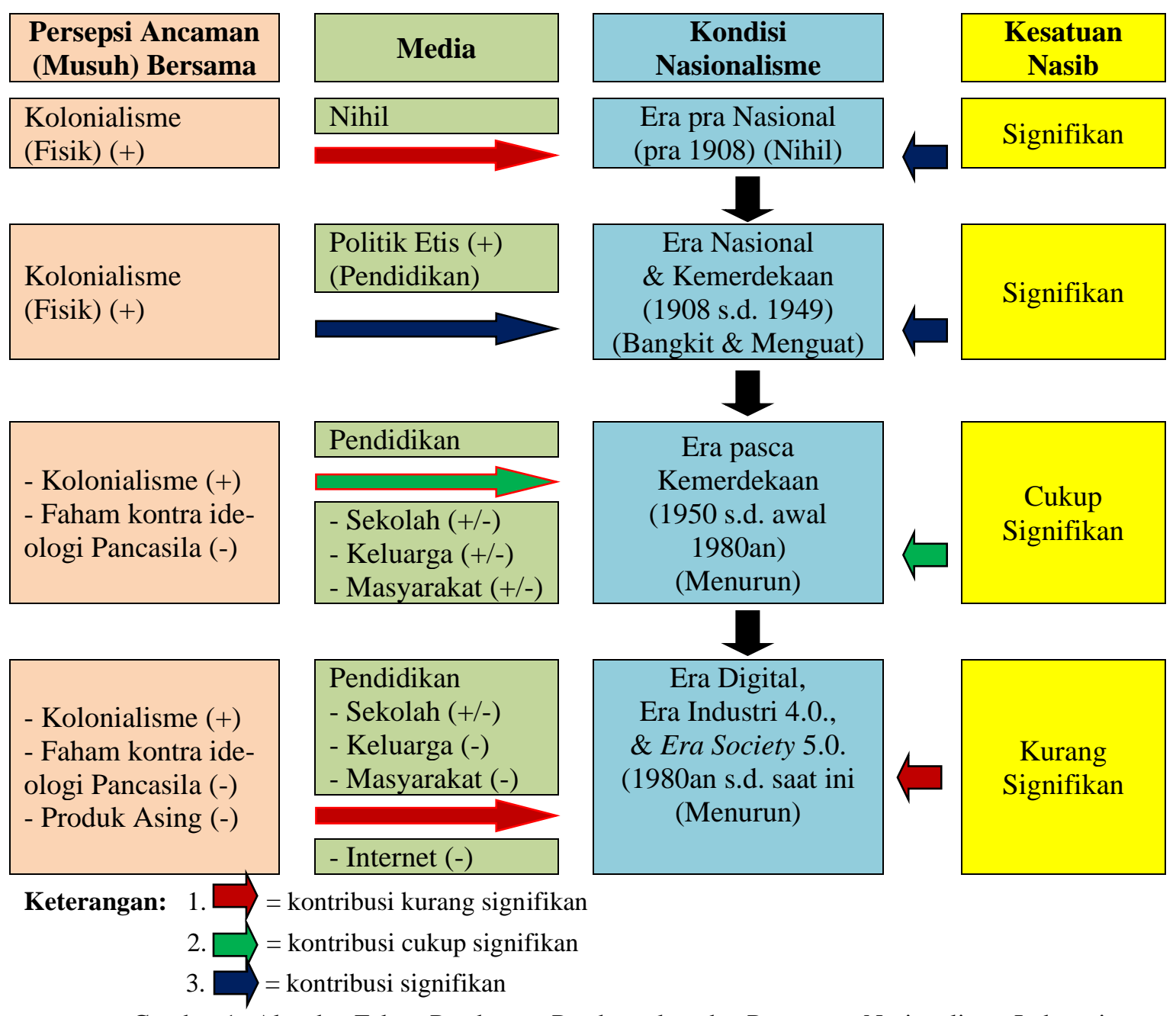

Gambar 1. Alur dan Faktor Pendorong Pembentukan dan Penguatan Nasionalisme Indonesia (Periodisasi Kondisi Nasionalisme di atas bertitik tolak pada awal era digital tahun 1980)[46] 
Untuk itu sosialisasi dan internalisasi berkelanjutan dapat diarahkan bagi minoritas kreatif (creative minority), kelompok individu yang memiliki self determining dan kreativitas untuk merespon lingkungan alamiah dan sosial. Tidak banyak, akan tetapi mereka memiliki peran vital sebagai panutan dan pemandu masyarakat kebanyakan dalam merespon tantangan zaman[47].

Representasi juga penting, karenanya mereka setidaknya terdiri dari berbagai elemen masyarakat seperti ibu rumah tangga, pemuda, profesi (pekerjaan) dan lain-lain. Pada sisi lain karakteristik geografis, demografis, dan sosio-kultural masyarakat yang demikian kompleks, tentu menjadi persoalan tersendiri. Untuk itu selektivitas peserta juga penting, dan ini dapat dilakukan dengan melibatkan institusi ataupun organisasi yang memiliki akses langsung atas masyarakat. Sebagai bentuk tindak lanjut, satu catatan yang juga tak kalah penting ialah mekanisme pelaksanaan, mekanisme kontrol, dan evaluasi untuk terus meningkatkan efektivitas pelaksanaan kegiatan dimaksud.

\section{KESIMPULAN}

Dari berbagai uraian di atas dapat ditarik kesimpulan bahwa konstruksi nasionalisme Indonesia terbangun di atas pondasi persepsi dan keyakinan yang sangat kuat dari seluruh elemen masyarakat atas keberadaan kolonialisme khususnya penjajahan Belanda sebagai ancaman luar atau musuh bersama atas eksistensi negara bangsa (nation-state) Indonesia. Dalam konteks ini, kesatuan nasib (chicksalgemeinshaft) dan pendidikan sebagai bagian dari politik balas budi (etische politiek) yang diterapkan oleh Belanda memiliki pengaruh yang sangat signifikan. Persepsi dan keyakinan tersebut terus mendominasi sepanjang perjalanan kehidupan kebangsaan Indonesia pada era pasca kemerdekaan dan era-era selanjutnya hingga memasuki Era Society 5.0. di mana ancaman luar (musuh bersama) telah bergeser dan semakin menjadi kompleks.

Kesenjangan (gap) di berbagai bidang seperti ekonomi, sosial, politik dan lain-lain yang mengemuka di era pasca pengakuan kedaulatan hingga kini telah berdampak pada terjadinya tumbuh kembang kecenderungan persepsi atas kesatuan nasib hanya sebagai romantisme sejarah belaka. Peran pendidikan formal (dari Sekolah Dasar hingga Perguruan Tinggi) sejauh ini juga belum cukup efektif, sementara keluarga dan masyarakat justeru menampilkan potret yang tidak jarang kontradiktif bahkan paradoksal. Wajah keluarga kerap tidak linier bahkan kontradiktif, sementara wajah masyarakat sebagai "laboratorium" sosialisasi dan internalisasi nilai cenderung permisif, bahkan tidak jarang pula kontradiktif dengan idealisme dan nilai-nilai nasionalisme itu sendiri. Logis bila kemudian berbagai upaya yang dilakukan dalam rangka membangun konsep ancaman luar (musuh bersama) atas eksistensi negara bangsa non tradisional (non fisik-militer) belum juga membuahkan sebagaimana diharapkan. Berbagai tahapan pendidikan nilai yang meliputi value thinking atau value cognitive, value affective, terlebih value action masyarakat secara keseluruhan belum dapat terlampaui.

Sebagai respon, menjadi prioritas untuk berupaya memberdayakan kembali peran keluarga dan masyarakat dalam pendidikan nasionalisme. Tidak cukup dengan mendukung kebijakan ataupun aturan sekolah, keluarga khususnya orang tua mutlak kembali turut serta aktif menjadi agent dalam sosialisasi dan internalisasi idealisme dan nilai-nilai nasionalisme sejak dini, demikian juga masyarakat sebagai "laboratorium" kehidupan kebangsaan. Kontekstualisasi persepsi dan keyakinan atas keberadaan ancaman (musuh) bersama juga amat penting. Di era di mana ancaman tidak lagi melulu bersifat tradisional (fisik-militer), berbagai faham kontra ideologi Pancasila, membanjirnya produk asing (import), dan lain-lain seyogyanya dikemukakan sebagai ancaman (musuh) bersama yang mutlak dipahamkan dan diyakinkan kepada seluruh elemen masyarakat. Untuk itu sosialisasi dan internalisasi nilai-nilai nasionalisme secara berkelanjutan khususnya kepada minoritas kreatif (creative minority) yang mepresentasikan berbagai elemen masyarakat seperti ibu rumah tangga, pemuda, profesi (pekerjaan) dan lain-lain dapat menjadi solusi. Dengan demikian pelibatan institusi ataupun organisasi yang memiliki akses langsung terhadap masyarakat secara berjenjang dapat menjadi 
alternatif. Hal ini dimungkinkan untuk dapat lebih menjamin efektivitas dan efisiensi dalam pelaksanaan sosialisasi dan internalisasi nilai-nilai nasionalisme itu sendiri. Satu catatan yang juga tidak boleh diabaikan adalah keberadaan kebijakan pemerintah yang relevan, serta mekanisme pelaksanaan, mekanisme kontrol, dan evaluasi secara terukur untuk terus meningkatkan efektivitas pelaksanaannya.

\section{UCAPAN TERIMA KASIH}

Ucapan terima kasih disampaikan atas diterbikannya naskah ini dalam Prosiding Seminar Nasional Sains Teknologi dan Inovasi Indonesia (Senastindo) 2021 kepada Gubernur Akademi Angkatan Udara dengan berbagai fasilitas dan kemudahan yang telah diberikan. Demikian juga kepada Koordinator Dosen dan Instruktur AAU atas kesempatan serta tiada henti memberikan motivasi, dan dorongan sehingga naskah ini dapat diselesaikan sesuai dengan rencana.

\section{REFERENSI}

[1] [Online]. Available: https://www.idntimes.com/science/discovery/xehi-dekirty/fakta-menarik-penyebabruntuhnya-negara-uni-soviet-exp-c1c2

[2] [Online]. Available:

https://www.google.com/search?q=sejarah+runtuhnya+yugoslavia\&oq=Sejarah+Runtuhnya+Yugoslavia\&aqs=c hrome.0.0i512j0i22i3012j69i60.39005j0j7\&sourceid=chrome\&ie=UTF

[3] Saptono, Dimensi-Dimensi Pendidikan Karakter: Wawasan, Strategi, dan Langkah Praktis. Jakarta: Erlangga, 2011.

[4] J. Pictet, The Geneva Convention and Law of War: Revue International de la Croix Rouge, 1962.

[5] T. Jacob, Tahun-tahun yang Sulit: Mari Mencintai Indonesia. Jakarta: Yayasan Obor Indonesia, 2001.

[6] A. Azra, Paradigma Baru Pendidikan Nasional: Rekonstruksi dan Demokratisasi. Jakarta: Kompas, 2002.

[7] D. Koesoema, Pendidikan Karakter di Zaman Keblinger. Jakarta: Grasindo, 2009.

[8] A. Wibowo, Pendidikan Karakter : Strategi Membangun Karakter Bangsa Berperadaban, 1st ed. Yogyakarta: Pustaka Pelajar, 2012.

[9] Nurmila and R. Fadilah, "Analisis Perhatian Wanita Karir terhadap Keberhasilan Anak dalam Keluarga di Dusun sawagi Kecamatan Patallassang Kabupaten Gowa,” J. Pendidik. Teknol. Pertan. Univ. Negeri Makassar, vol. 3, pp. 223-227, 2017, doi: https://doi.org/10.26858/jptp.v3i2.5711.

[10] Z. Daradjat, Kesehatan Mental, 1982nd ed. Jakarta: Gunung Agung.

[11] E. Setiawan, Nasionalisme, 3rd ed. Kamus Besar Bahasa Indonesia (KBBI) Kamus versi online/daring (dalam jaringan). [Online]. Available: https://kbbi.web.id/nasionalisme

[12] H. Kohn and terj. Sumantri, Nationalism, its Meaning and History, terj Sumantri,. Jakarta: Pembangunan, 1961.

[13] E. Renan and S. ed. Woolf, Nationalism in Europe, 1815 to the Present. USA and Canada: Routledge, 2003.

[14] S. Maradona, "Ide Pancasila Sudah Dipikirkan Sejak 1918,” Jun. 01, 2020. [Online]. Available: https://republika.co.id/berita/lm3r53/ide-pancasila-sudah-dipikirkan-sejak-1918-3

[15] Q. Y. Zakiyah and H. A. Rusdiana, Pendidikan Nilai, Kajian Teori dan Praktik di Sekolah, vol. 1. Bandung: Pustaka Setia, 2014. [Online]. Available: http://digilib.uinsgd.ac.id/8789/1/Buku\%20Pendidikan\%20Nilai.pdf

[16] D. K. Windrati, "Pendidikan Nilai sebagai Suatu Strategi dalam Pembentukan Kepribadian Siswa," J. Form. J. Ilm. Pendidik. MIPA, vol. 1, no. 1, pp. 40-47, 2011.

[17] R. Sukardi, "Pendidikan Nilai; Mengatasi Degradasi Moral Keluarga," presented at the Prosiding Seminar Nasional Pendidikan FKIP UNTIRTA, 2017. [Online]. Available: https://jurnal.untirta.ac.id/index.php/psnp/article/view/305-312

[18] K. Amalia and D. Maulipaksi, "Tri Pusat Pendidikan: Guru, Keluarga dan Masyarakat," Kemdikbud, Agustus 2017. [Online]. Available: https://www.kemdikbud.go.id/main/blog/2017/08/tri-pusat-pendidikan-gurukeluarga-dan-masyarakat

[19] Haryanto, "Pendidikan Karakter Menurut Ki Hadjar Dewantara," Kurikulum dan Teknologi Pendidikan FIP $U N Y$, Yogyakarta. [Online]. Available: http://staffnew.uny.ac.id/upload/131656343/penelitian/PENDIDIKAN+KARAKTER+MENURUT+KI+HAJAR +DEWANTORO.pdf

[20] I. Shofwan, "Tri Pusat Pendidikan," unnes.ac.id, Apr. 24, 2018. [Online]. Available: http://blog.unnes.ac.id/imampnf/2018/04/24/tri-pusat-pendidikan/

[21] H. Wriggins, Y. Muhaimin, and C. Mc. Andrews., "Integrasi Bangsa," in Masalah-Masalah Pembangunan Politik, Yogyakarta: Gadjahmada University Press, 1991.

[22] J. Subianto, "PERAN KELUARGA, SEKOLAH, DAN MASYARAKAT DALAM PEMBENTUKAN KARAKTER BERKUALITAS," Edukasia J. Penelit. Pendidik. Islam, vol. 8, no. 2, Art. no. 2, Sep. 2013, doi: 10.21043/edukasia.v8i2.757. 
[23] N. N. Nailufar, "Maksud Ucapan Soekarno: ‘Perjuanganku Lebih Mudah...,"” Kompas, Agustus 2020. [Online]. Available: https://www.kompas.com/skola/read/2020/08/10/083500369/maksud-ucapan-soekarno-perjuanganku-lebih-mudah--?page=all

[24] T. Ervianto, "kepentingan-asing-di-balik-freedom-flotilla-west-papua," detiknews, Agustus 2013. [Online]. Available: https://news.detik.com/kolom/d-2346026/kepentingan-asing-di-balik-freedom-flotilla-west-papua

[25] J. Oetama, "Pidato Kebudayaan Mochtar Lubis, Menguak Enam Sifat Manusia Indonesia," National Geographic Indonesia, Agustus 2016. [Online]. Available: https://nationalgeographic.grid.id/read/13306246/pidato-kebudayaan-mochtar-lubis-menguak-enam-sifatmanusia-indonesia

[26] S. Hajati and A. Yani, Geografi Politik. Bandung: Refika Aditama, 2007.

[27] [Online]. Available: http://eep.saefulloh.fatah.tripod.com/id189.htm

[28] [Online]. Available: https://www.worldcat.org/title/malu-aku-jadi-orang-indonesia/oclc/606380077

[29] G. Myrdal, The Challenge of World Poverty: A World Anti-poverty Program in Outline. Random House Trade Paperbacks, 1970.

[30] S. Adisusilo, Pembelajaran Nilai Karakter; Konstruksi dan VCT sebagai Inovasi Pendekatan Pembelajaran Afektif. Depok: Raja Grafindo Persada, 2012.

[31] F. C. Farisa, "Survei LSI: Dibanding Identitas Keagamaan dan Kesukuan, Nasionalisme Rakyat Indonesia Lebih Tinggi,” Kompas, Nov. 03, 2019. [Online]. Available: https://nasional.kompas.com/read/2019/11/03/survei-lsidibanding-identitas-keagamaan-dan-kesukuan-nasionalisme-rakyat.

[32] B. Marley, "Kontestasi Nasionalisme Papua dan Nasionalisme Indonesia Sebelum dan Sesudah Orde Baru," presented at the Seminar Akhir Tahun Integrasi Sosial Ekonomi, Sosial Budaya, dan Sosial Politik Papua ke Indonesia: Tinjauan Akademik, Jakarta, Desember 2014. [Online]. Available: https://adoc.pub/kontestasinasionalisme-papua.html

[33] F. J. Kuwado, “Jokowi dan Arti ‘Revolusi Mental,”' Kompas, Oktober 2014, [Online]. Available: https://nasional.kompas.com/read/2014/10/17/22373441/Jokowi.dan.Arti.Revolusi.Mental

[34] "Sejarah Masih Terus Berulang," Kompas, Mar. 29, 2018. [Online]. Available: https://www.kompas.id/baca/opini/2018/03/29/sejarah-masih-terus-berulang

[35] J. A. C. Mackie, Konfrontasi: The Indonesia-Malaysia Dipute 1963-1966. Kuala Lumpur: Oxford University Press, 1974.

[36] I. M. A. Arsana, "Penyelesaian Sengketa Ambalat dengan Delimitasi Maritim: Kajian Geospasial dan Yuridis," J. Ilm. FISIP, vol. 1, no. 1, 2010, [Online]. Available: https://www.academia.edu/332143/Penyelesaian_Sengketa_Ambalat_dengan_Delimitasi_Maritim_Kajian_Geos pasial_dan_Yuridis

[37] "Posko Ganyang Malaysia Dibuka di Bojonegoro Posko Ganyang Malaysia Dibuka di Bojonegoro," detiknews, Sep. 02, 2010. [Online]. Available: https://news.detik.com/berita-jawa-timur/d-1433948/posko-ganyangmalaysia-dibuka-di-bojonegoro.

[38] S. Rachmayanti, “Jokowi Geram RI Banjir Produk Impor, Ekonom: Ya Salah Sendiri!,” Sindonews, Mar. 08, 2021. [Online]. Available: https://ekbis.sindonews.com/read/358136/34/jokowi-geram-ri-banjir-produk-imporekonom-ya-salah-sendiri-1615201381

[39] P. R. Hadinoto, "Nasionalisme: Malaysia, Lecut Nasionalisme Reaktif," Jakarta 45, Politika Konstitusi Pancasila Indonesia, Nov. 02, 2021. [Online]. Available:

https://jakarta45.wordpress.com/2009/09/02/nasionalisme-malaysia-lecut-nasionalisme-reaktif/

[40] A. M. Sardiman and D. L. Amurwani, Sejarah Indonesia. Jakarta: Kemendikbud, 2017.

[41] Y. Kusumawati, "Peran Ganda Perempuan Pemetik Teh," vol. 4, no. 2, pp. 157-167, Sep. 2012.

[42] D. Susilawati and I. Rezkisari, "Ketika Orang Tua Keberatan Anaknya Dihukum di Sekolah," Republika, Mar. 26, 2014. [Online]. Available: https://www.republika.co.id/berita/humaira/ibu-anak/14/03/26/n311mw-ketikaorang-tua-keberatan-anaknya-dihukum-di-sekolah

[43] W. Purwaningsih, "Jurnal Keluarga dalam Mewujudkan Pendidikan Nilai Sebagai Upaya Mengatasi Degradasi Nilai Moral,” J. Pendidik. Sosiol. Dan Hum., vol. 1, no. 1, pp. 43-55, 2010, doi: http://dx.doi.org/10.26418/jpsh.v1i1.379.

[44] Nurhasanah, "Peran Masyarakat dalam Lembaga Pendidikan," Fondatia J. Pendidik. Dasar, vol. 1, no. 1, pp. 61-67, Mar. 2007, doi: https://doi.org/10.36088/fondatia.v1i1.87.

[45] G. Wibisono, "Media Baru dan Nasionalisme Anak Muda: Pengaruh Penggunaan Medsos 'Good News From Indonesia' terhadap Perilaku Nasionalisme,” J. Studi Pemuda, vol. 6, no. 2, pp. 590-604, Sep. 2017, doi: https://doi.org/10.22146/studipemudaugm.39264.

[46] P. Unkris, [Online]. Available: https://p2k.unkris.ac.id/id3/1-3065-2962/Revolusi-Digital_103540_unkris_p2kunkris.html

[47] M. D. Kurniawan, "Spiritualitas, Minoritas Kreatif, dan Peradaban Islam Klasik (5): Minoritas Kreatif," Gana Islamika, Sep. 29, 2018. [Online]. Available: https://ganaislamika.com/spiritualitas-minoritas-kreatif-danperadaban-islam-klasik-5-minoritas-kreatif/ 